\title{
CONTEMPORARY MIGRATORY MOVEMENTS IN THE MUNICIPALITY OF TRSTENIK
}

\author{
SAŠA MILOSAVLJEVIĆ ${ }^{1^{*}}$ \\ ${ }^{1}$ Faculty of Natural Sciences and Mathematics, University of Priština, Kosovska Mitrovica, Serbia
}

\begin{abstract}
Municipality of Trstenik located in spacious valley of Zapadna Morava, has always provided favorable conditions for the settlement of the population and the development of settlements. After the World War II, there was a need for recruiting a large number of people because of a huge development of metal industry in Trstenik, and that fact attract the immigrants from the area of Rasina, Aleksandrovačka Župa, Podibra, Lepenica, Levač and Temnić. The ratio between autochthonous and migrant population according to 1961 Census was 69\%:31\%, while the same ratio for the 2011 census was $59 \%: 41 \%$. Nearly a quarter $(24 \%)$ of total number of immigrants immigrated in the inter-census period from 1981. to 1991, and almost all (94\% of immigrants) immigrated from the same area of the republic. The process of emigration particularly intensified in the early nineties of the XX century when young and highly educated population emigrate, and the main reason for that was a poor economic situation.
\end{abstract}

Keywords: population, migrations, Trstenik, Serbia.

\section{INTRODUCTION}

Modern migratory movements in the world today represent an important demographic determinant. The intensity of migration movements is an important indicator of socioeconomic and demographic situation in a country. Analyzing data from the last 2011 Census, it's evident that we have increasing emigration from the central and southern parts of Serbia, and vast resettlement to Belgrade region. In the last twenty years due to the unfavorable socio-economic situation the municipality of Trstenik has a problem with the outflow of population outside of the municipality, and too there is a problem with certain migratory movements inside the Trstenik. The emigration is primarly characteristic for youth who after graduation does not return to the home municipality, they rather prefer to stay in great economic centers where they start their families and where they have a job. These migration trends inevitably affect the municipality in terms of development and function of the settlement.

\section{MATERIAL AND METHODS}

The metodology in this paper is according to the subject, objectives and tasks of the research. Field studies are carried through directs and systematics observation, as well as conducting surveys and interviews. The historical method contents the use of literature, written documents and other archive material and presents us knowledge about the past of the municipality of Trstenik. Data were collected in public institutions and in the Statistical Office of the Republic of Serbia.

\section{IMMIGRATION AND EMIGRATION COMPONENT}

The settlement of Trstenik area had started at 1791. and the adoption of the firman, which allowed Serbs free trade of cattle and gave them certain privileges. The population has migrated from the Toplica, Župa, Rasina, from Kosovo and Srem too.

Intensive settlement continues after victories in the first and second Serbian uprising, population from Montenegro (people from Kolašin mostly), Sjenica, Novi Pazar and from Pešter (mountain area) immigrated to this area (Popović, 1968). In the postwar period, there have been significant changes and shifts in population structure. At the beginning of the application of the first five-year plans and the establishment of industrial enterprises 'Prva petoletka', during this period from 1948 to 1961, Trstenik was great place for inhabitants due to increased demand for labor. Population from surrounding villages and a population from the surrounding areas Rasina, Aleksandrovačka Župa, Podibra, Lepenica, Levač and Temnić, then from Vojvodina, Kosovo and Metohija, Bosnia and Herzegovina, Croatia, Slovenia, Macedonia, Montenegro and a certain number of those who were born abroad start to migrate to Trstenik (Medojević et al., 2011).

According to 1961 Census we conclude that the indigenous population on the territory of the municipality of Trstenik seemed more than two thirds of population of the municipality $(69.03 \%)$ or relatively 40,485 inhabitants. Immigrant population was significantly lower $-18,166$, or $30.97 \%$ of the population of the municipality. The difference between autohthonous and migrant population was 22,319 inhabitants (Table 1). Further development of the metal industry and opportunities for employment and favorable conditions of life had caused that municipality of Trstenik became the immigration area. 
Table 1. Autohthonous and migrant population in the municipality of Trstenik (1961 Census)

\begin{tabular}{|c|c|c|c|c|c|}
\hline \multirow{2}{*}{ Municipality } & \multicolumn{2}{|c|}{ AUTOHTHONOUS } & \multicolumn{2}{|c|}{ MIGRANT } & \multirow{2}{*}{ TOTAL } \\
\cline { 2 - 5 } & Number & $\%$ & Number & $\%$ & \\
\hline Trstenik, Velika Drenova & 40.485 & 69.03 & 18.166 & 30.97 & 58.651 \\
\hline
\end{tabular}

Source of data: 1961 Census of Population, Households and Dwellings, Book 12, Migrations, Data by municipalities and cities, Statistical Office of the Republic of Serbia, Belgrade, 1966.

The results of 2011 Census confirmed the process of immigration in the municipality, and show that in the municipality of Trstenik it is still outnumber the indigenous population $(25.415$ or $59.11 \%$ of the population of the municipality) in relation to the migrant population (17.581 or $40.89 \%$ of the population of the municipality), except the thing

that disproportion between these two populations is much lower and it is only 7.834 inhabitants or $18.22 \%$ of the population of the municipality (Table 2). Inhabitants born on territory of municipality Trstenik are concentrated in the other (rural) areas, while on the other side, the urban environment was more attractive for immigrants.

Table 2. Autohthonous and migrant population in the municipality of Trstenik (2011 Census)

\begin{tabular}{|c|c|c|c|c|c|}
\hline \multirow{2}{*}{ MUNICIPALITY } & \multicolumn{2}{|c|}{ AUTOHTHONOUS } & \multicolumn{2}{|c|}{ MIGRANT } & \multirow{2}{*}{ TOTAL } \\
\cline { 2 - 5 } & Number & $\%$ & Number & $\%$ & \\
\hline Trstenik & 25.415 & 59.11 & 17.581 & 40.89 & 42.996 \\
\hline
\end{tabular}

Source of data: 2011 Census of Population, Households and Dwellings, Book 9, Migrations, Data by municipalities and cities, Statistical Office of the Republic of Serbia, Belgrade, 2013.

According to Census 1961 figures from Statistical Office of the Republic of Serbia showthat until that time, the largest population on the territory of today's municipality had moved before 1940. - 6,863 or $38.05 \%$ immigrant population. After this period there is a period from 1946 to 1952 . with 3,848

immigrants or $21.32 \%$ and after that there is a period from 1953 to 1957 with 3,176 immigrants or $17.60 \%$, and period from 1958 to 1961 with 3,022 immigrants or $16.74 \%$ of the total immigrant population. During World War II there was a 1,136 inhabitants migrants or $6.29 \%$ (Table 3).

Table 3. The population in the municipality of Trstenik according to time of immigration (1961 Census)

\begin{tabular}{|c|c|c|}
\hline \multirow{2}{*}{ YEAR } & Municipalities of Trstenik and Velika Drenova \\
\cline { 2 - 3 } & Number & 38.05 \\
\hline before 1940 & 6.863 & 6.29 \\
\hline $1941-1945$ & 1.136 & 21.32 \\
\hline $1946-1952$ & 3.848 & 17.60 \\
\hline $1953-1957$ & 3.176 & 16.74 \\
\hline $1958-1961$ & 3.022 & 100 \\
\hline TOTAL & 18.045 & \\
\hline
\end{tabular}

Source of data: 1961 Census of Population, Households and Dwellings, Book 12, Migrations, Data by municipalities and cities, Statistical Office of the Republic of Serbia, Belgrade, 1966.

Results from 2011 Census confirmed the same trend with certain derogations from the above mentioned reasons, cause until the 1963, Velika Drenova existed as an independent municipality and after abolishment of this municipality part of the settlement was added to municipality of Trstenik and other part of territory was added to municipality of Kruševac. Thus, according to 2011 Census of population, we have a situation that the smallest number of immigrants was in the period 2001-2005. precisely 999 immigrants or $5.69 \%$ and in the period from 1991 to $1995,1,055$ immigrants or $6 \%$. The construction of the industrial enterprises 'Prva petoletka' which during the period from 1950 to 1990 was one of the largest manufacturers of hydraulics and pneumatics in Europe. That contributed to the municipality of Trstenik to become immigration area, so in that period before 1980 year, 8,463 inhabitants were moved or $48.13 \%$ of the total immigrant population. After this period the following periods from 1981 to 1985 . (1,673 immigrants9.52\%), 1986-1990. (1,448 immigrants - 8.24\%). A smaller number of immigrants was recorded during the period between 1996 and $2000(1,211-6.88 \%)$ and during the period after 2006 
(1,361-7.75\%). For the 1,371 inhabitants or $7.79 \%$ of immigrants is not reliably established when they moved (Table 4).

Table 4.The population in the municipality of Trstenik according to time of immigration (2011 Census)

\begin{tabular}{|c|c|c|}
\hline \multirow{2}{*}{ YEAR } & \multicolumn{2}{|c|}{ Municipality of Trstenik } \\
\cline { 2 - 3 } & Number & 48.13 \\
\hline 1980. and earlier & 8.463 & 9.52 \\
\hline $1981-1985$ & 1.673 & 8.24 \\
\hline $1986-1990$ & 1.448 & 6.00 \\
\hline $1991-1995$ & 1.055 & 6.88 \\
\hline $1996-2000$ & 1.211 & 5.69 \\
\hline $2001-2005$ & 999 & 7.75 \\
\hline 2006. and later & 1.361 & 7.79 \\
\hline Unknown year & 1.371 & 100 \\
\hline TOTAL & 17.581 & \\
\hline
\end{tabular}

Source of data: 2011 Census of Population, Households and Dwellings, Book 9, Migrations, Data by municipalities and cities, Statistical Office of the Republic of Serbia, Belgrade, 2013.

Based on the results according to 1961 Census, we can conclude that today's municipality of Trstenik largest population has been moved from different places but from same municipality - 9,671 inhabitants or $53.27 \%$ immigrant population. After that the population that moved from other municipalities of the same republic - 7,676 residents or $42.28 \%$, while the much smaller number of immigrants moved from another Socialist Republic or the Autonomous Province - 792 inhabitants or $4.38 \%$ of immigrant population. The number of immigrants from other countries is negligible (Table 5). This trend of immigration has been continued after forty years, that remains that the most immigrants comes from the same or other municipalities, which leads us to the conclusion that the municipality of Trstenik is not attractive for immigrants from remote areas, but it attracts the immigrants from smaller distances.

Table 5. Migrants population in the municipality of Trstenik according to the areas (1961. Census)

\begin{tabular}{|c|c|c|}
\hline \multirow{2}{*}{ AREA } & \multicolumn{2}{|c|}{ Municipalities of Trstenik and Velika Drenova } \\
\cline { 2 - 3 } & Number & 53.27 \\
\hline Different places same municipality & 9.671 & 42.28 \\
\hline Different municipality same republic & 7.676 & 4.38 \\
\hline Different republic and autonomous province & 792 & 0.07 \\
\hline Different country & 14 & 100 \\
\hline TOTAL & 18.153 & \\
\hline
\end{tabular}

Source of data: 1961 Census of Population, Households and Dwellings, Book 12, Migrations, Data by municipalities and cities, Statistical Office of the Republic of Serbia, Belgrade, 1966.

According to the 2011 Census of population, the highest number of immigrants consists from the population from the territory of the same municipality 8.390 or $47.73 \%$, after that the immigrants from other areas 5,518 or $31.39 \%$, and immigrants from other municipalities 2,582 or $14.68 \%$. The smallest proportion of immigrants are those from the former Yugoslav republics - 865 , or $4.93 \%$, and other countries, 219 or only $1.25 \%$ of the total number of immigrant population (Table 6). Area of municipality of Trstenik was quite attractive for immigration until the beginning of the last decade of the twentieth century. Reasons for that was an employment, opportunities for individuals in their professions, the opportunity to acquire higher income as well as the ability to have suitable living conditions (Đurđev, 1998).

The disintegration of former Yugoslavia, beginning of the civil war in the former state, international sanctions, inflation, poverty and the difficult economic situation were reasons for the difficult living conditions in the municipality. The largest number of active population was employed at the firm complex 'Prva petoletka', but because of losing a large market of former Yugoslavia and large parts of the European market this firm was operating with major problems. This led to the first emigration of highly educated people with their families to Belgrade and abroad. After the democratic changes in the year 2000, the 
situation has not significantly improved, so we can conclude that immigrants were mostly part of younger and middle age the emigration intensified in the last fifteen years. The population.

Table 6. Migrants population in the municipality of Trstenik according to the areas (2011. Census)

\begin{tabular}{|c|c|c|}
\hline \multirow{2}{*}{ AREA } & \multicolumn{2}{|c|}{ Municipality of Trstenik } \\
\cline { 2 - 3 } & Number & 47.73 \\
\hline Different settlement same municipality & 8.390 & 14.68 \\
\hline Different municipality same republic & 2.582 & 31.39 \\
\hline Different areas & 5.518 & 4.93 \\
\hline Former republics of SFRJ & 865 & 1.25 \\
\hline Other countries & 219 & 0.02 \\
\hline Unknown & 4 & 100 \\
\hline TOTAL & 17.581 & \\
\hline
\end{tabular}

Source of data: 2011 Census of Population, Households and Dwellings, Book 9, Migrations, Data by municipalities and cities, Statistical Office of the Republic of Serbia, Belgrade, 2013.

As a result of crisis, the development of the municipality was almost stopped and parts of companies and enterprises have failed. Trstenik is a traditional community that every year sends a large number of students to college, mostly in Belgrade. Students who successfully completed their studies they start working for private companies in Belgrade or go to abroad where they remain to live, and start their families. And students who fail to successfully finalize the study, also remain in large university centers of Serbia because it's easier to find a job and secure existence.

Young people are not only moving out from the municipality center, but from all villages in the municipality. By the last decade of the twentieth century the population has migrated from villages to urban or suburban areas mainly because of work in the city. A lack of jobs in the city center caused the extension of the migration of population to other cities. Rural households that rely on agriculture have difficult task to generate income, especially since the state is constantly increasing taxes, prices of seeds, fuel prices and without guaranteed purchase prices of agricultural products. The lack of adequate social, cultural and sports life make things even worse in villages around Trstenik. Young people who do not want to stay with parents migrate to areas where it is easier to find a job, solve existential problems and easier to secure good life for themselves and their families. It is estimated that 84 inhabitants of the municipality of Trstenik went to abroad on temporaty stay. 68 of them are on temporary work and 16 of them are members of their families. 41 resident was from urban area at work and five residents were members of their families. There is a similar number of residents in abroad from the villages of the municipality, out of 43 inhabitants, 32 of them were working and 11 of them are members of their families. Villages which present the greatest emigrational center to foreign countries are: Riđevštica, Jasikovica, Brezovica and Stublica. The municipality of Trstenik has markedly developed agricultural production and therefore the need for agricultural workers is bigger. In large villages in the municipality, especially in the Velika Drenova and Stopanja, year after year the number of seasonal migrant workers from Bulgaria and Romania is increasing.

\section{COMMUTING-DAYTIME POPULATION}

Part of the population of the municipality of Trstenik presenting the urban-rural and rural-urban commuting pattern. This part of the population belongs to the employees of the city's economy, youth who study in the municipal center and the urban population employed in rural areas, which together belong to the group of continuous commuters.

According to the 2011 census, the municipality of Trstenik have 4,088 active migrants or $9.5 \%$ of the total population of the municipality. In other (rural) settlements the largest number of active migrants are 3,360 compared to 728 who live in urban areas. The highest percentage of migrants $(76.1 \%)$ work in different settlement in the same municipality, mainly in the municipal center. A small number of inhabitants, 292 of them, or $7.1 \%$, have to go to work in other municipalities. It is interesting to compare active migrants from rural and urban areas. From rural areas $85.1 \%$ of residents commute to Trstenik (mainly for work in the firm 'Prva petoletka'), while only 5.5\% migrates to other municipalities, to other areas migrates 684 inhabitants, or $16.7 \%$. The situation is different in urban settlements where more than half of the population commute to other areas, 370 of them or $50.8 \%$ of commuters, after them there is a big number of commuters inside the municipality 251 migrants or $34.5 \%$, while the minimum commuters travel to other municipalities (Vrnjačka Banja, Kruševac, Kraljevo) with 185 migrants or 5.5\% (Table 7). 
Table 7. Commuters of active population in the municipality of Trstenik (2011. Census)

\begin{tabular}{|c|c|c|c|c|c|c|c|c|c|}
\hline \multirow{2}{*}{ Settlement } & \multirow{2}{*}{$\begin{array}{c}\text { TOTAL } \\
\text { ACTIVE }\end{array}$} & \multicolumn{2}{|c|}{ Same municipality } & \multicolumn{2}{c|}{$\begin{array}{c}\text { Different } \\
\text { municipality }\end{array}$} & \multicolumn{2}{|c|}{ Different } & \multicolumn{2}{c|}{ Different } \\
\cline { 3 - 10 } & Number & $\%$ & Number & $\%$ & Number & $\%$ & Number & $\%$ \\
\hline $\begin{array}{c}\text { Trstenik } \\
\text { (municipality) }\end{array}$ & 4.088 & 3.111 & 76.1 & 292 & 7.1 & 684 & 16.7 & 1 & 0.1 \\
\hline City settlements & 728 & 251 & 34.5 & 107 & 14.7 & 370 & 50.8 & - & - \\
\hline $\begin{array}{c}\text { Other } \\
\text { settlements }\end{array}$ & 3.360 & 2.860 & 85.1 & 185 & 5.5 & 314 & 9.3 & 1 & 0.1 \\
\hline
\end{tabular}

Source of data: 2011 Census of Population, Households and Dwellings, Book 11, Daily migrants, Data by municipalities and cities, Statistical Office of the Republic of Serbia, Belgrade, 2013.

The second group of continuous commuters consists of youth or students. Pupils and students have a share of $35.2 \%$ in total daily migration in the municipality of Trstenik. Most of these migrants originated from other (rural) settlements, 2,006 compared to 214 in urban areas. In other settlements in the municipality study 1,538 pupils and students, while in the other municipalities of the Republic of Serbia study 282 pupils and students from the municipality of Trstenik. In other areas of the republic study 399 pupils and students or $17.9 \%$ (Table 8). Because of Technical school and gymnasium in Trstenik the largest number of students come from rural areas. The number of students from the municipality of Trstenik who are studying at the Technical College and private universities in Trstenik is much lower. The largest number of students from the municipality of Trstenik study in large university centers of Serbia. Occasional daily migrations are done from time to time. People who come to Trstenik for selling goods at markets shopping in the city, or people with some personal needs and private business are participating in occasional daily migrations.

Table 8. Commuters students in the municipality of Trstenik (2011. Census)

\begin{tabular}{|c|c|c|c|c|c|c|c|c|c|}
\hline \multirow[t]{2}{*}{ Settlement } & \multirow[t]{2}{*}{ TOTAL } & \multicolumn{2}{|c|}{ Same municipality } & \multicolumn{2}{|c|}{$\begin{array}{c}\text { Different } \\
\text { municipality }\end{array}$} & \multicolumn{2}{|c|}{$\begin{array}{c}\text { Different } \\
\text { area }\end{array}$} & \multicolumn{2}{|c|}{ Other country } \\
\hline & & Number & $\%$ & Number & $\%$ & Number & $\%$ & Number & $\%$ \\
\hline $\begin{array}{c}\text { Trstenik } \\
\text { (municipality) }\end{array}$ & 2.220 & 1.538 & 69.3 & 282 & 12.7 & 399 & 17.9 & 1 & 0.1 \\
\hline City settlements & 214 & 20 & 9.34 & 55 & 25.7 & 139 & 64.9 & - & - \\
\hline Other settlements & 2.006 & 1.518 & 75.7 & 227 & 11.3 & 260 & 12.9 & 1 & 0.1 \\
\hline
\end{tabular}

Source of data: 2011 Census of Population, Households and Dwellings, Book 11, Daily migrants, Data by municipalities and cities, Statistical Office of the Republic of Serbia, Belgrade, 2013.

\section{CONCLUSION}

Geographical position of Trstenik has always provided favorable conditions for the settlement of population. The main settlement of Trstenik area starts from 1791 when immigrants from Montenegro, Pešter, Toplica and Kosovo and Metohija came to Trstenik. After the World War II, more intensive development of agriculture and particulary the opening of industrial enterprises 'Prva petoletka' make that the municipality of Trstenik became an immigrant region. During this period, in each inter-census interval there wasn't less than 3,000 newly settled inhabitants in the municipality. This trend lasted until the early nineties of the twentieth century. The disintegration of the former state, war in the region, international sanctions and the difficult economic situation cause that municipality of Trstenik becomes emigration area. From the municipality of Trstenik population emigrate to Belgrade and to other regional centers of the republic, mostly young, educated and fertile age population. This process entails a number of other processes where the most important are depopulation and demographic aging. State and local governments must use their stimulus measures to try to slow the process of emigration by creating favorable living and working environment for people who are living in rural and smaller urban areas.

\section{REFERENCES}

Đurđev, B. 1998. Geografija stanovništva. Novi Sad: Prirodnomatematički fakultet.

Medojević, J., Pavlović, M., \& Milosavlević, S. 2011. Demograhic analysis of forced migrations in Kosovo and 
Metohia from 1999 to 2011, Global Modern Demographic problems: Migration and emigrational policy. Moscow: Russian Academy of Sciences - Russian State University for the Humanities. pp. 124-135.

Popović, M. 1968. Trstenik i okolina. Trstenik: SO Trstenik.

Republički zavod za statistiku. 2013. Popis stanovništva, domaćinstava i stanova u 2011. godini. In Migracije. Knjiga 9, Beograd.
Republički zavod za statistiku. 2013. Popis stanovništva, domaćinstava i stanova u 2011. godini. In Dnevni migranti. Knjiga 11. Beograd.

Zavod za statistiku. 1966. Popis stanovništva, domaćinstava i stanova 1961, In Migraciona obeležja - rezultati za naselja. Knjiga XII, Beograd. 